\title{
TINDAKAN PENCEGAHAN COVID-19 OLEH MAHASISWA UNIVERSITAS UDAYANA
}

\author{
Ni Putu Ita Dewi Astiti, Made Pasek Kardiwinata* \\ Program Studi Kesehatan Masyarakat Fakultas Kedokteran Universitas Udayana \\ Jalan PB. Sudirman, Denpasar, Bali 80232
}

\begin{abstract}
ABSTRAK
Kasus COVID-19 terus meningkat, usia remaja dan dewasa muda digolongkan sebagai kelompok yang memiliki tingkat kepatuhan yang masih rendah dalam langkah-langkah mencegah penyebaran COVID-19. Tujuan penelitian untuk melihat hubungan antara karakteristik sosiodemografi, riwayat penyakit komorbid, dan tingkat pengetahuan dengan tindakan pencegahan COVID-19 oleh mahasiswa Universitas Udayana. Desain penelitian adalah penelitian observasional dengan rancangan studi potong lintang terhadap 80 mahasiswa terpilih melalui teknik multistage random sampling. Hasil penelitian menunjukkan $61,25 \%$ mahasiswa menerapkan tindakan baik dalam pencegahan COVID-19. Mahasiswa sering mengunjungi tempat keramaian 47,50\%, kurang menjaga jarak $28,75 \%$, dan sering sentuh mulut, hidung, dan mata sebelum cuci $30 \%$. Hasil uji regresi logistik sederhana menunjukkan jenis kelamin $(\mathrm{OR}=1,9)$ status pekerjaan orang tua $(\mathrm{OR}=1,62)$, dan riwayat penyakit komorbid pada orang tua $(\mathrm{OR}=1,68)$ sebagai faktor risiko terhadap tindakan pencegahan COVID-19. Sedangkan usia, fakultas, dan pengetahuan menunjukkan bukan sebagai faktor risiko terhadap tindakan pencegahan COVID-19. Bagi peneliti yang tertarik dengan topik ini dapat meneliti faktor determinan memengaruhi tindakan pencegahan COVID-19 yang buruk seperti sering mengunjungi tempat keramaian, dan sentuh area mulut, hidung, dan mata sebelum cuci tangan.
\end{abstract}

Kata kunci : COVID-19, Tindakan Pencegahan, Mahasiswa Universitas Udayana

\begin{abstract}
The COVID-19 case continues to rise, adolescents and young adults are classified as groups with lower level of compliance in the measures preventing the spread of COVID-19. The purpose of research is to identify the association between the characteristics of sociodemographic, the history of comorbid disease in parents, and knowledge with the preventive measures of COVID-19 by udayana university students. The design of this study is an observational study with a cross-sectional study design on 80 students selected through multistage random sampling. The results showed that $61,25 \%$ of students had good COVID-19 practice. Students often visit crowded places $47,50 \%$, do not keep a distance of $28,75 \%$, and often touch the mouth, nose, and eye before washing their hands $30 \%$. The simple logistic regression test showed that gender $(\mathrm{OR}=1,9)$, parent's occupational status $(\mathrm{OR}=1,62)$, and comorbid history in parents $(\mathrm{OR}=1,68)$ as risk factors of COVID-19 prevention measures. Meanwhile, age, faculty, and knowledge are not risk factors for COVID-19 prevention measures. For reaseachers who are interested in this topic, expected to examine the determinants factors that influence poor COVID-19 prevention measures such as frequent public visits, often touching the mouth, nose, and eye before washing their hands.
\end{abstract}

Keyword: COVID-19, Prevention, Udayana University Student

\section{PENDAHULUAN}

COVID-19 pertama kali dilaporkan di Kota Wuhan, Cina pada Desember 2019 dan dinyatakan sebagai Public Health Emergency of International Concern oleh WHO pada 30 Januari 2020 (WHO, 2020b). COVID-19 disebabkan oleh virus SARS$\mathrm{CoV}-2$ dengan penularan yang cepat dari orang ke orang lewat droplet (WHO, 2020a). Manifestasi klinis orang yang terinfeksi COVID-19 mulai dari pneumonia ringan (81\%), pneumonia sedang (14\%), hingga penyakit kritis (5\%) (Wu \& McGoogan, 2020). Gejala paling umum orang yang terinfeksi COVID-19 yaitu demam, batuk, mialgia atau kelelahan. Adapun gejala lainnya seperti sakit kepala, diare, produksi sputum, 
hemoptisis, dan mengalami dispnea (Huang et al., 2020). Orang yang terkonfirmasi COVID-19 ada yang tidak menunjukkan gejala atau bersifat asimptomatik, akan tetapi virus SARSCoV-2 masih bisa ditularkan ke orang lain (Kemenkes RI, 2020).

Provinsi Bali termasuk dalam 10 besar provinsi terbanyak kasus COVID-19. Data kasus COVID-19 sampai tanggal 08 Pebruari 2021 yaitu total jumlah kasus terkonfirmasi sebanyak 28.277 kasus (Satgas COVID-19, 2021). Pada kelompok usia tua, orang dengan penyakit komorbid diantaranya penyakit kardiovaskular, ginjal, penyakit paru-paru kronik, diabetes, hipertensi, asma, dan maligna merupakan kelompok berisiko tinggi yang meningkatkan keparahan penyakit apabila terinfeksi COVID-19 (CDC, 2020; Wu \& McGoogan, 2020).

Pemerintah telah mengupayakan berbagai kebijakan dalam menurunkan tingkat penularan COVID-19 di masyarakat diantaranya memperketat disiplin protokol kesehatan, menguatkan 3T (testing, tracing, dan treatment), pembatasan mobilitas masyarakat, dan pelaksanaan vaksinasi COVID-19. Namun peningkatan jumlah kasus COVID-19 terus terjadi setiap harinya. Peningkatan kasus COVID-19 terjadi pada usia muda berhubungan dengan tingkat mobilisasi yang tinggi di masyarakat yakni mempunyai kehidupan sosial yang aktif dan jejaring sosial yang besar (Andrews, Foulkes, \& Blakemore, 2020; Cohen, Hoyt, \& Dull, 2020; Wrzus, Hänel, Wagner, \& Neyer, 2013).

Dalam survei BPS tahun 2020 terkait tingkah laku masyarakat selama pandemi
COVID-19 diperoleh tingkat kepatuhan pencegahan COVID-19 pada usia 17-30 tahun yaitu sebesar 8,0\% responden jarang menggunakan masker, sebesar 21,5\% respoden jarang menggunakan handsanitizer/disinfektan, sebesar 26,6\% responden jarang cuci tangan pakai sabun dalam 20 detik, sebesar 18,7\% responden jarang menghindari jabat tangan, sebesar $25,6 \%$ responden jarang menghindari kerumunan, dan sebesar $28,3 \%$ responden jarang menjaga jarak minimal 1 meter (BPS RI, 2020). Selain itu, ketidakpatuhan usia muda dalam menerapkan pencegahan COVID-19 dapat dipengaruhi oleh kurangnya pengetahuan akan dampak bahaya bagi orang lain terutama pada kelompok yang berisiko tinggi seperti usia lanjut dan orang dengan riwayat penyakit komorbid apabila terinfeksi COVID-19.

Universitas Udayana merupakan perguruan tinggi negeri tertua yang terdapat di Provinsi Bali. Mahasiswa Universitas Udayana notabenenya memiliki pengetahuan tinggi diharapkan menjadi agent of change untuk menyebarkan informasi dan mengedukasi masyarakat dalam mengurangi peningkatan kasus COVID-19 di Bali. Kebijakan Universitas Udayana dalam mencegah penularan COVID-19 di lingkungan kampus telah diterapkan sejak pertama kasus COVID-19 ada di Indonesia diantaranya menerapkan kuliah secara daring, mencegah kegiatan kemahasiswaan yang menimbulkan kerumunan, memberlakukan work from home (WFH) pada sebagian pegawai dan staf. Dalam hasil pengamatan yang dilakukan, beberapa mahasiswa 
Universitas Udayana menunjukkan praktik pencegahan COVID-19 masih tergolong kurang seperti tidak menjaga jarak, tidak menggunakan masker dengan benar, dan merokok. Sehubung dengan permasalahan tersebut lalu ditetapkan tujuan penelitian untuk mengetahui hubungan asosiasi antara karakteristik sosiodemografi, riwayat penyakit komorbid, dan pengetahuan dengan tindakan pencegahan COVID-19 oleh mahasiswa Universitas Udayana.

\section{METODE}

Desain penelitian adalah penelitian observasional dengan rancangan studi potong lintang. Lokasi penelitian dilaksanakan di Universitas Udayana dan periode penelitian dilaksanakan bulan April - Juli 2021. Kriteria inklusi sampel penelitian ini adalah mahasiswa status aktif pada semester 4 sampai semester akhir serta belum wisuda. Kriteria eksklusi sampel penelitian ini adalah mahasiswa menolak menjadi responden penelitian. Sampel dari penelitian ini adalah mahasiswa Universitas Udayana yang telah menempuh pendidikan minimal 4 semester atau 2 tahun sebanyak 80 orang terpilih melalui teknik multistage random sampling. Data dikumpulkan secara online melalui menyebarkan kuesioner berupa google form melalui whatsapp dan line. Data dikumpulkan meliputi karakteristik sosiodemografi mahasiswa (usia, jenis kelamin, fakultas, status pekerjaan orang tua), riwayat penyakit komorbid pada orang tua, pengetahuan terkait COVID-19, dan tindakan pencegahan COVID-19 pada mahasiswa Universitas Udayana. Data dianalisis secara statistik deskriptif dan uji beda proporsi dengan uji regresi logistik sederhana menggunakan software analysis (Stata SE/ 12.0). Ethical Clearance dengan nomor 1374/UN14.2.2.VII.14/LT/2021 merupakan kelaikan etik dari Komisi Etik Penelitian (KEP) Fakultas Kedokteran Universitas Udayana. 
HASIL

Tabel 1. Gambaran Karakteristik dan Riwayat Penyakit Komorbid pada Orang Tua Responden

\begin{tabular}{|c|c|c|}
\hline Variabel & Frekuensi & Persentase $(\%)$ \\
\hline \multicolumn{3}{|l|}{ Usia } \\
\hline 19 tahun & 4 & $5 \%$ \\
\hline 20 tahun & 24 & $30 \%$ \\
\hline 21 tahun & 36 & $45 \%$ \\
\hline 22 tahun & 16 & $20 \%$ \\
\hline \multicolumn{3}{|l|}{ Jenis Kelamin } \\
\hline Perempuan & 58 & $72,50 \%$ \\
\hline Laki-laki & 22 & $27.50 \%$ \\
\hline \multicolumn{3}{|l|}{ Angkatan } \\
\hline 2017 & 24 & $30 \%$ \\
\hline 2018 & 47 & $58,75 \%$ \\
\hline 2019 & 9 & $11,25 \%$ \\
\hline \multicolumn{3}{|l|}{ Fakultas } \\
\hline Kedokteran & 38 & $47,50 \%$ \\
\hline Bukan Kedokteran & 42 & $52,50 \%$ \\
\hline \multicolumn{3}{|l|}{ Status Pekerjaan Orang Tua } \\
\hline Bekerja & 76 & $95 \%$ \\
\hline Tidak Bekerja & 4 & $5 \%$ \\
\hline \multicolumn{2}{|l|}{ Orang Tua } & \\
\hline Ya & 17 & $21,25 \%$ \\
\hline Tidak & 63 & $78,75 \%$ \\
\hline
\end{tabular}

Berdasarkan tabel 1, maka diketahui responden berusia 21 tahun sebesar 36 orang (45\%). Berjenis kelamin perempuan yaitu 58 orang (72,50\%). Berdasarkan angkatan sebagian besar responden merupakan angkatan 2018 yaitu 47 orang (58,75\%). Berdasarkan fakultas, sebagian responden bukan berasal dari Fakultas Kedokteran yaitu 42 orang $(52,50 \%)$ dan responden dari Fakultas Kedokteran yaitu
38 orang $(47,50 \%)$. Selain itu, hampir semua orang tua responden dalam penelitian ini dalam status bekerja yaitu 76 orang (95\%). Diketahui riwayat penyakit komorbid pada orang tua mahasiswa Universitas Udayana sebagian besar yaitu 63 orang $(78,75 \%)$ responden tidak memiliki riwayat penyakit komorbid pada orang tua. 
Tabel 2. Proporsi Pengetahuan Mahasiswa Universitas Udayana Mengenai COVID-19 Variabel Frekuensi $\quad$ Persentase (\%)

\section{Pengetahuan}

$\begin{array}{lcc}\text { Baik } & 73 & 91,25 \% \\ \text { Kurang } & 7 & 8,75 \%\end{array}$

Berdasarkan tabel 2, maka diketahui sebagian besar responden mempunyai Tabel 3. Gambaran Aspek Tindakan Pencegahan COVID-19 Oleh Mahasiswa Universitas Udayana

\begin{tabular}{|c|c|c|c|}
\hline No & Pertanyaan & Jawaban & $\begin{array}{c}\text { Frekuensi } \\
(\%)\end{array}$ \\
\hline 1. & $\begin{array}{l}\text { Apakah Anda selalu menggunakan masker saat } \\
\text { keluar rumah, kumpul dengan teman dan } \\
\text { keluarga, dan di tempat keramaian? }\end{array}$ & $\begin{array}{c}\text { Ya } \\
\text { Tidak }\end{array}$ & $\begin{array}{l}\text { (77) } 96,25 \% \\
\text { (3) } 3,75 \%\end{array}$ \\
\hline 2. & $\begin{array}{l}\text { Apakah Anda menggunakan masker menutupi } \\
\text { hidung, mulut dan dagu? }\end{array}$ & $\begin{array}{c}\text { Ya } \\
\text { Tidak }\end{array}$ & $\begin{array}{l}(76) 95 \% \\
(4) 5 \%\end{array}$ \\
\hline 3. & $\begin{array}{l}\text { Apakah Anda mencuci tangan pakai sabun pada } \\
\text { air mengalir atau menggunakan handsanitizer } \\
\text { saat berada di tempat keramaian? }\end{array}$ & $\begin{array}{c}\text { Ya } \\
\text { Tidak }\end{array}$ & $\begin{array}{l}\text { (79) } 98,75 \% \\
\text { (1) } 1,25 \%\end{array}$ \\
\hline 4. & $\begin{array}{l}\text { Apakah Anda selalu menjaga jarak minimal satu } \\
\text { meter saat bertemu orang lain? }\end{array}$ & $\begin{array}{c}\text { Ya } \\
\text { Tidak }\end{array}$ & $\begin{array}{l}\text { (57) } 71,25 \% \\
\text { (23) } 28,75 \%\end{array}$ \\
\hline 5. & $\begin{array}{l}\text { Apakah Anda sering mengunjungi tempat } \\
\text { keramaian seperti mall, kafe, pantai, dan tempat } \\
\text { wisata? }\end{array}$ & $\begin{array}{c}\text { Ya } \\
\text { Tidak }\end{array}$ & $\begin{array}{l}\text { (38) } 47,50 \% \\
\text { (42) } 52,50 \%\end{array}$ \\
\hline 6. & $\begin{array}{l}\text { Apakah Anda menggunakan tissue atau lengan } \\
\text { atas bagian dalam untuk menutupi mulut dan } \\
\text { hidung saat batuk dan bersin? }\end{array}$ & $\begin{array}{c}\text { Ya } \\
\text { Tidak }\end{array}$ & $\begin{array}{l}\text { (77) } 96,25 \% \\
\text { (3) } 3,75 \%\end{array}$ \\
\hline 7. & $\begin{array}{l}\text { Apakah Anda sering menyentuh area mata, } \\
\text { hidung, dan mulut sebelum mencuci tangan? }\end{array}$ & $\begin{array}{c}\text { Ya } \\
\text { Tidak }\end{array}$ & $\begin{array}{l}(24) 30 \% \\
(56) 70 \%\end{array}$ \\
\hline 8. & $\begin{array}{l}\text { Apakah Anda langsung berganti pakaian } \\
\text { sebelum bersentuhan dengan anggota keluarga } \\
\text { saat tiba di rumah? }\end{array}$ & $\begin{array}{c}\text { Ya } \\
\text { Tidak }\end{array}$ & $\begin{array}{l}\text { (63) } 78,75 \% \\
\text { (17) } 21,25 \%\end{array}$ \\
\hline
\end{tabular}

Berdasarkan tabel 3, sebagian besar responden selalu menggunakan masker saat keluar rumah $(96,25 \%)$ dan menggunakan masker menutupi hidung, mulut, dan dagu (95\%). Sebagian besar responden mencuci tangan (98,75\%). Sebagian besar responden selalu menjaga pengetahuan baik sebesar 91,25\% dan pengetahuan kurang sebesar 8,75\%. 
sebelum cuci tangan (70\%) dan sebagian

tiba

di rumah

$(78,75 \%)$.

responden langsung berganti pakaian saat

Tabel 4. Proporsi Tindakan Pencegahan COVID-19 Oleh Mahasiswa Universitas Udayana Variabel Frekuensi Persentase (\%)

\section{Tindakan}

Baik

49

$61,25 \%$

Kurang

31

$38,75 \%$

Berdasarkan tabel 4, diketahui proporsi mahasiswa menerapkan tindakan baik dalam pencegahan COVID-
19 sebesar 61,25\% dan tindakan kurang dalam pencegahan COVID-19 sebesar $38,75 \%$.

Tabel 5. Tindakan Pencegahan COVID-19 Oleh Mahasiswa Universitas Udayana berdasarkan Karakteristik, Riwayat Penyakit Komorbid pada Orang Tua, dan Pengetahuan

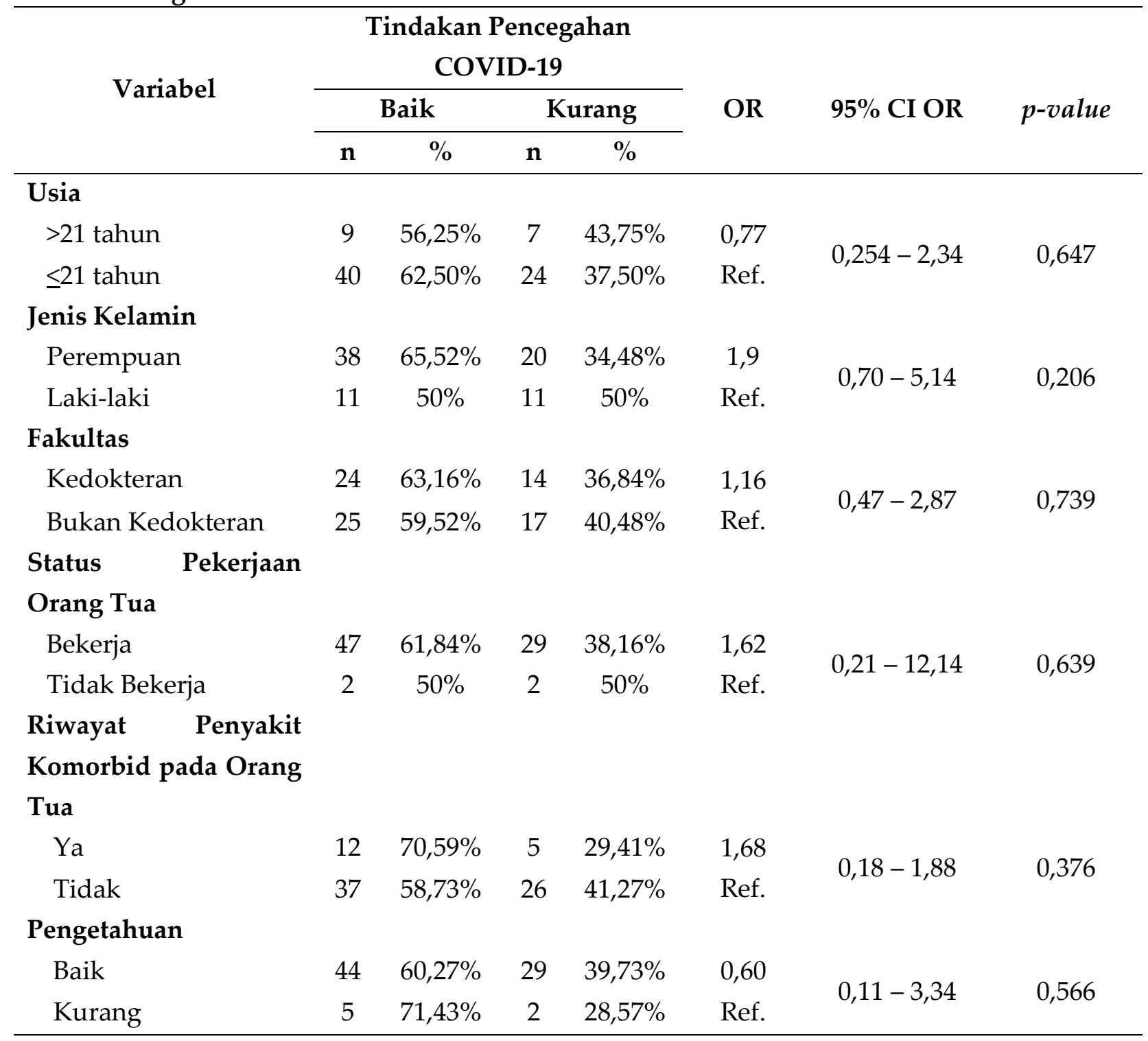


Berdasarkan tabel 5, maka hasil penelitian menunjukkan tidak ada beda proporsi antara responden yang berusia >21 tahun menerapkan tindakan baik dalam pencegahan COVID-19 yaitu $56,25 \%$ dengan responden yang berusia $\leq 21$ tahun menerapkan tindakan baik dalam pencegahan COVID-19 yaitu $62,50 \%$. Responden yang berusia $\leq 21$ tahun berisiko 0,77 kali menerapkan tindakan kurang dalam pencegahan COVID-19 dibandingkan responden berusia $>21$ tahun.

Berdasarkan karakteristik jenis kelamin, maka hasil penelitian menunjukkan ada beda proporsi antara jenis kelamin perempuan menerapkan tindakan baik dalam pencegahan COVID19 yaitu 65,52\% dengan laki-laki menerapkan tindakan baik dalam pencegahan COVID-19 yaitu 50\%. Responden yang berjenis kelamin perempuan berpeluang 1,9 kali menerapkan tindakan baik dalam pencegahan COVID-19 daripada responden berjenis kelamin laki-laki.

Berdasarkan karakteristik fakultas, maka hasil penelitian menunjukkan tidak ada beda proporsi antara responden dari Fakultas Kedokteran menerapkan tindakan baik dalam pencegahan COVID19 yaitu 63,16\% dengan responden yang bukan dari Fakultas Kedokteran menerapkan tindakan baik dalam pencegahan COVID-19 yaitu 59,52\%. Responden yang bukan dari Fakultas Kedokteran berisiko 1,16 kali menerapkan tindakan kurang dalam pencegahan COVID-19 dibandingkan responden dari Fakultas Kedokteran.
Berdasarkan status pekerjaan orang tua, maka hasil penelitian menunjukkan ada beda proporsi antara orang tua responden yang status bekerja menerapkan tindakan baik dalam pencegahan COVID-19 yaitu 61,84\% dengan responden yang status orang tua tidak bekerja menerapkan tindakan baik dalam pencegahan COVID-19 yaitu 50\%. Responden orang tua bekerja berpeluang 1,62 kali menerapkan tindakan baik dalam pencegahan COVID-19 dibandingkan responden orang tua tidak bekerja.

Berdasarkan riwayat penyakit komorbid pada orang tua, maka hasil penelitian menunjukkan ada beda proporsi antara responden yang memiliki riwayat penyakit komorbid pada orang tua menerapkan tindakan baik dalam pencegahan COVID-19 yaitu 70,59\% dengan responden yang tidak memiliki riwayat penyakit komorbid pada orang tua menerapkan tindakan baik dalam pencegahan COVID-19 yaitu 58,73\%. Responden yang memiliki riwayat penyakit komorbid pada orang tua berpeluang 1,68 kali menerapkan tindakan baik dalam pencegahan COVID-19 daripada responden tidak memiliki riwayat penyakit komorbid pada orang tua.

Berdasarkan pengetahuan, maka hasil penelitian menunjukkan tidak ada beda proporsi antara responden berpengetahuan baik menerapkan tindakan baik dalam pencegahan COVID19 yaitu 60,27\% dengan responden berpengetahuan kurang menerapkan tindakan baik dalam pencegahan COVID19 yaitu 71,43\%. Responden yang mempunyai pengetahuan kurang berisiko 
0,60 kali menerapkan tindakan kurang dalam pencegahan COVID-19 dibandingkan responden mempunyai pengetahuan baik.

\section{PEMBAHASAN}

Tindakan pencegahan COVID-19 pada penelitian ini ditunjukkan dari pernyataan mahasiswa mengenai tindakan pencegahan COVID-19 meliputi menjaga jarak (physical distancing), penggunaan masker, kebersihan tangan dan etika bersin dan batuk, tidak menyentuh area wajah, dan mengganti baju. Berdasarkan hasil penelitian ini, proporsi mahasiswa Universitas Udayana yang menerapkan tindakan baik dalam pencegahan COVID-19 yaitu 61,25\%. Hasil penelitian memperlihatkan tindakan pencegahan COVID-19 oleh mahasiswa Universitas Udayana sudah cukup baik. Hasil penelitian Peng et al. (2020) menunjukkan proporsi tindakan proaktif terkait pencegahan COVID-19 pada mahasiswa di Cina sebesar 87,9\%. Hasil penelitian Olaimat et al. (2020) menunjukkan bahwa praktik risiko rendah terhadap COVID-19 pada mahasiswa di Yordania sebesar 84,3\%.

Berdasarkan karakteristik sosiodemografi, sebagian responden menerapkan tindakan baik dalam pencegahan COVID-19 yaitu usia >21 tahun $56,25 \%$ berbanding usia $\leq 21$ tahun $62,50 \%$. Dilihat dari jenis kelamin, sebagian responden menerapkan tindakan baik dalam pencegahan COVID-19 yaitu jenis kelamin perempuan 65,52\% berbanding lak-laki 50\%. Dilihat dari asal fakultas sebagian responden menerapkan tindakan baik dalam pencegahan COVID-
19 yaitu dari Fakultas Kedokteran 63,16\% berbanding bukan Fakultas Kedokteran $59,52 \%$. Dilihat dari status pekerjaan orang tua sebagian responden menerapkan tindakan baik dalam pencegahan COVID19 yaitu responden dengan orang tua bekerja $61,84 \%$ berbanding orang tua tidak bekerja 50\%. Dilihat dari riwayat penyakit komorbid pada orang tua sebagian responden menerapkan tindakan baik dalam pencegahan COVID-19 yaitu memiliki riwayat penyakit komorbid pada orang tua $70,59 \%$ berbanding tidak memiliki riwayat penyakit komorbid pada orang tua $58,73 \%$. Dilihat dari pengetahuan sebagian responden yang menerapkan tindakan baik dalam pencegahan COVID-19 yaitu pengetahuan baik $60,27 \%$ berbanding pengetahuan kurang $71,43 \%$.

Tindakan pencegahan COVID-19 pada mahasiswa Universitas Udayana tergolong cukup baik. Hal tersebut terlihat dari mahasiswa yang menggunakan masker saat keluar rumah sebesar 96,25\%, memakai masker menutupi mulut, hidung dan dagu sebesar 95\%, cuci tangan dengan sabun/menggunakan handsanitizer sebesar $98,75 \%$, menerapkan etika batuk dan bersin sebesar 96,25\%. Beberapa hal tersebut menunjukkan tindakan pencegahan COVID-19 yang dilakukan oleh mahasiswa Universitas Udayana sudah baik. Hal tersebut dapat dipengaruhi oleh lamanya terpapar informasi mengenai COVID-19 baik lewat media cetak dan elektronik, ataupun melalui organisasi kemahasiswaan di lingkungan universitas/fakultas. Selain itu, berbagai kebijakan-kebijakan pemerintah diterapkan secara tegas dalam upaya 
mengendalikan penyebaran COVID-19 mulai dari tingkat nasional hingga tingkat desa.

Akan tetapi, belum optimalnya tindakan pencegahan COVID-19 pada mahasiswa Universitas Udayana disebabkan seperti kurang jaga jarak minimal satu meter sebesar $28,75 \%$, sering mengunjungi tempat keramaian seperti mall, kafe, pantai, dan tempat wisata sebesar $47,50 \%$. Selain itu, mahasiswa Universitas Udayana sering sentuh mulut, hidung, dan mata sebelum cuci tangan sebesar 30\%. Hal tersebut dapat disebabkan selama masa pandemi COVID-19 mahasiswa merasa jenuh hanya tinggal di rumah. Pemerintah telah kembali membuka tempat wisata di beberapa daerah, serta adanya kelonggaran dan penerapan sanksi yang kurang tegas bagi yang melanggar. Beberapa waktu lalu, masyarakat Bali banyak melaksanakan upacara keagamaan yang melibatkan banyak orang. Beberapa masyarakat tidak mengikuti protokol kesehatan yang ketat saat berada di pura. Tindakan ini dapat menjadi berisiko secara signifikan dalam penularan COVID-19 yangmana faktor tersebut terbukti berkontribusi pada penyebarannya (Olaimat et al., 2020). Penerapan physical distancing dapat menghindari seseorang dari penularan virus melalui droplet dengan menjaga jarak dan menghindari kerumunan ataupun keramaian (Syadidurrahmah et al., 2020).

Karakteristik sosiodemografi mahasiswa Universitas Udayana sebagian besar berjenis kelamin perempuan sebesar $72,50 \%$. Dalam penelitian ini menunjukkan bahwa ada beda proporsi antara jenis kelamin perempuan $65,25 \%$ dibanding jenis kelamin laki-laki 50\% dengan tindakan baik dalam pencegahan COVID-19 dengan diperoleh nilai OR = 1,9. Jenis kelamin perempuan berpeluang 1,9 kali menerapkan tindakan baik dalam pencegahan COVID-19 dibandingkan lakilaki. Hasil penelitian ini sejalan dengan penelitian Saefi et al. (2020) menunjukkan jenis kelamin sebagai faktor risiko terhadap praktik pencegahan COVID-19 diperoleh nilai $\mathrm{OR}=2,02$. Penelitian lain oleh Olaimat et al. (2020) memperlihatkan ada hubungan bermakna antara jenis kelamin dengan tindakan pencegahan COVID-19 pada mahasiswa di Yordania. Hasil penelitian tersebut mengungkapkan bahwa perempuan merasa lebih khawatir akan kemungkinan terinfeksi COVID-19 dan menerapkan praktik berisiko rendah. Jenis kelamin perempuan mempunyai kepedulian lebih terhadap kondisi kesehatan dan lingkungannya, sehingga perempuan memiliki kecenderungan berperilaku baik dibandingkan dengan laki-laki (Sari et al., 2020).

Status pekerjaan orang tua dapat memengaruhi responden melakukan tindakan pencegahan COVID-19. Status pekerjaan berpengaruh dalam meningkatkan sosial ekonomi dan kesejahteraan masyarakat. Seseorang yang memiliki pekerjaan dengan penghasilan tetap cenderung dapat memenuhi kebutuhan hidupnya. Faktor utama yang memengaruhi perilaku pencegahan masyarakat salah satunya adalah pekerjaan (Gao et al., 2020). Dalam penelitian ini status pekerjaan orang tua menunjukkan bahwa sebagian besar yaitu 
95\% responden dengan orang tua status bekerja. Hasil penelitian ini menunjukkan bahwa ada beda proporsi antara responden orang tua bekerja 61,84\% dibanding responden orang tua tidak bekerja $50 \%$ dengan tindakan baik dalam pencegahan COVID-19 dengan diperoleh nilai $\mathrm{OR}=1,62$. Responden dengan status orang tua bekerja berpeluang 1,62 kali menerapkan tindakan baik dalam pencegahan COVID-19 dibandingkan mahasiswa dengan orang tua tidak bekerja. Hal tersebut dapat disebabkan perusahaan/instansi mewajibkan para pekerjanya mengikuti anjuran pemerintah dalam mengurangi penularan COVID-19 di tempat kerja. Tingginya aktivitas para pekerja yang mengharuskan berhadapan langsung dengan masyarakat luas akan meningkatkan perilaku pencegahan COVID-19.

Selain karakteristik sosiodemografi, riwayat penyakit komorbid pada orang tua juga dapat memengaruhi responden menerapkan tindakan baik dalam pencegahan COVID-19. Dalam hasil penelitian hanya sebagian kecil responden yaitu $21,25 \%$ yang memiliki riwayat penyakit komorbid pada orang tua. Dalam penelitian ini menunjukkan bahwa ada beda proporsi antara responden yang memiliki riwayat penyakit komorbid pada orang tua $70,59 \%$ dibanding responden yang tidak memiliki riwayat penyakit komorbid pada orang tua $58,73 \%$ dengan tindakan baik dalam pencegahan COVID19 dengan diperoleh nilai $\mathrm{OR}=1,68$. Responden dengan riwayat penyakit komorbid pada orang tua berpeluang 1,68 kali menerapkan tindakan baik dalam pencegahan COVID-19 dibandingkan responden yang tidak memiliki riwayat komorbid pada orang tua. Hal tersebut dapat disebabkan seseorang yang anggotanya memiliki penyakit komorbid merasa lebih berisiko terhadap keparahan penyakit dan kematian akibat COVID-19. Seseorang yang memiliki riwayat penyakit komorbid pada orang tua cenderung lebih banyak belajar mengenai pencegahan, sikap yang lebih positif, dan melakukan tindakan proaktif dalam pencegahan COVID-19.

Karakteristik sosiodemografi lainnya yang tidak menunjukkan ada beda proporsi dengan tindakan pencegahan COVID-19 yaitu usia dan fakultas. Berdasarkan hasil analisis diperoleh usia rata-rata mahasiswa Universitas Udayana yaitu 21 tahun. Usia $\leq 21$ tahun termasuk usia remaja, usia remaja tergolong kelompok yang memiliki tingkat kepatuhan yang masih rendah terhadap perilaku pencegahan COVID-19. Sebagian besar mahasiswa Universitas Udayana berusia $\leq 21$ tahun sebesar $80 \%$. Dalam hasil penelitian memperlihatkan tidak ada beda proporsi antara usia $>21$ tahun $56,25 \%$ dibanding usia $\leq 21$ tahun $62,50 \%$ dengan tindakan baik dalam pencegahan COVID-19 dengan diperoleh nilai OR = 0,77 . Responden berusia $\leq 21$ tahun berisiko 0,77 kali menerapkan tindakan kurang dalam pencegahan COVID-19 dibandingkan berusia $>21$ tahun. Hasil penelitian ini sejalan dengan penelitian Saefi et al. (2020) mengungkapkan usia bukan faktor risiko terhadap tindakan pencegahan COVID-19 pada mahasiswa di Indonesia dengan nilai $\mathrm{OR}=1,06$. Hal ini disebabkan usia tidak secara langsung dapat memengaruhi tindakan seseorang 
perlu adanya faktor perantara seperti sikap dan faktor lainnya. Hal seperti ini dicetuskan oleh Lawrence Green dalam Nursalam (2014) bahwa perlu adanya faktor pemungkin dan penguat dalam perubahan perilaku.

Mahasiswa dari kedokteran notabenenya mempelajari ilmu kedokteran/kesehatan dan telah mendapatkan praktik/pelatihan mengenai kesehatan. Tanggungjawab sebagai tenaga kesehatan di masa depan mewajibkan mereka bersikap lebih positif dan bertindak proaktif dalam situasi darurat kesehatan (Peng et al., 2020). Berdasarkan karakteristik fakultas menunjukkan bahwa sebagian besar responden berasal dari bukan Fakultas Kedokteran sebesar $52,50 \%$. Dalam hasil penelitian memperlihatkan tidak ada beda proporsi antara mahasiswa dari Fakultas Kedokteran 63,16\% dibanding mahasiswa bukan dari Fakultas Kedokteran 59,52\% dengan tindakan baik dalam pencegahan COVID-19 dengan diperoleh nilai OR = 1,16. Mahasiswa dari bukan Fakultas Kedokteran berisiko 1,16 kali menerapkan tindakan kurang dalam pencegahan COVID-19 dibandingkan mahasiswa dari Fakultas Kedokteran.

Hasil penelitian ini sejalan dengan penelitian Hatabu et al. (2020) mengungkapkan fakultas bukan faktor risiko terhadap tindakan pencegahan COVID-19 pada mahasiswa di Jepang dengan nilai $\mathrm{OR}=1,12$. Penelitian lain oleh Alzoubi et al. (2020) yang menunjukkan tidak terdapat perbedaan signifikan praktik pencegahan COVID-19 di antara mahasiswa kedokteran dan bukan mahasiswa kedokteran di Yordania. Hasil penelitian tersebut mengungkapkan bahwa media informasi yang cakupannya lebih luas dan tindakan yang lebih tegas diterapkan oleh pemerintah Yordania setelah WHO mengumumkan sebagai pandemi COVID-19 yakni dengan pemberlakuan lockdown melalui pelaksanaan keadaan darurat dan kebijakan jam malam yg ketat.

Hasil analisis menunjukkan pengetahuan responden sebagian besar mempunyai pengetahuan baik yaitu 91,25\%. Dalam hasil penelitian memperlihatkan tidak ada beda proporsi antara pengetahuan baik $60,27 \%$ dibanding pengetahuan kurang 71,43\% dengan tindakan baik dalam pencegahan COVID-19 dengan diperoleh nilai OR = 0,60 . Responden berpengetahuan kurang berisiko 0,60 kali menerapkan tindakan kurang dalam pencegahan COVID-19 daripada responden berpengetahuan baik. Hasil penelitian sejalan dengan Ferdous et al. (2020) menunjukkan bahwa pengetahuan bukan faktor risiko terhadap tindakan pencegahan COVID-19 dengan nilai $\mathrm{OR}=1,10$. Hasil penelitian tersebut mengungkapkan bahwa penyebaran dan informasi kesehatan masyarakat yang kurang optimal mengenai COVID-19 sehingga terjadinya kesenjangan pendidikan yang signifikan. Kelompok orang dewasa muda kemungkinan secara signifikan memiliki pengetahuan yang lebih akurat.

Dilihat dari berbagai aspek pengetahuan mengenai COVID-19, sebagian besar responden memiliki pengetahuan yang baik bahkan di atas 90\%. Hal tersebut dapat disebabkan oleh lokasi penelitian, karakteristik responden 
dan paparan terhadap informasi mengenai COVID-19. Lokasi penelitian dilakukan di Universitas Udayana yang merupakan perguruan tinggi negeri yang terdapat di Bali. Mahasiswa sebagai agent of change dapat mengedukasi masyarakat untuk menerapkan tindakan baik dalam pencegahan COVID-19. Dalam pandemi COVID-19 Universitas Udayana melaksanakan KKN secara daring kombinasi. Sehingga mahasiswa harus dibekali ilmu dan informasi yang valid mengenai COVID-19. Tingkat pendidikan responden yang lebih tinggi memengaruhi tingkat pengetahuan responden mengenai COVID-19. Tingkat pendidikan akan memengaruhi tingkat pengetahuan seseorang. Derajat pendidikan tinggi berbanding lurus dengan pengetahuan seseorang.

Proporsi responden yang menerapkan tindakan baik dalam pencegahan COVID-19 pada mahasiswa berpengetahuan kurang yaitu 71,43\% lebih besar dibandingkan pada mahasiswa yang memiliki pengetahuan baik. Hal ini dapat disebabkan tindakan bukan hasil langsung dipengaruhi oleh pengetahuan. Menurut Notoatmodjo (2014) dalam Syakurah \& Moudy (2020) pengetahuan dipengaruhi oleh lingkungan dan pengalaman individu yang selanjutnya bisa diekspresikan dan diyakini sehingga timbul motivasi.

Tidak terdapatnya hubungan pengetahuan dengan tindakan pencegahan COVID-19 dimungkinkan adanya faktor lain yang memengaruhi perilaku seseorang. Faktor lain seperti kebijakan pemerintah kemungkinan dapat memengaruhi perilaku pencegahan
COVID-19. Menurut Suharto (2008) dalam Tuwu (2020) kebijakan adalah prinsip atau cara bertindak yang dijadikan sebagai tumpuan dalam pengambilan keputusan. Selain itu kebijakan adalah keputusan atau tindakan yang dipilih secara langsung dalam mengelola atau mendistribusikan hasil kekayaan alam, keuangan, dan manusia bagi kepentingan rakyat.

Dalam keadaan darurat kesehatan masyarakat pemerintah Indonesia membuat berbagai kebijakan dalam mengatasi pandemi COVID-19 yaitu (1) Penerapan Protokol Kesehatan, (2) Physical Distancing (Pembatasan Fisik), (3) Social Distancing (Pembatasan Sosial), Work/Study From Home (Bekerja/Belajar dari rumah), (5) Pemberlakukan Pembatasan Kegiatan Masyarakat (PPKM), dan (6) Vaksinasi COVID-19. Pemerintah bertindak tegas apabila ada pelanggaran akan diberikan sanksi atau hukuman untuk meningkatkan kedisplinan masyarakat terkait perilaku pencegahan COVID-19. Kebijakan pemerintah dalam upaya mengatasi pandemi COVID-19 menimbulkan perubahan adat-istiadat, tradisi, interaksi masyarakat, dan pola perilaku masyarakat (Tuwu, 2020).

Faktor lain seperti dukungan dari tokoh masyarakat bisa merubah tingkah laku seseorang. Menurut Green dalam Syadidurrahmah et al. (2020) mengatakan bahwa faktor penguat seseorang dalam melakukan perilaku kesehatan dipengaruhi oleh dukungan dari tokoh masyarakat. Tokoh masyarakat dipercayai berperan penting seperti pemimpin yang berwibawa sehingga bisa menambah antusiasme rakyatnya. Upaya pemerintah 
dalam mengendalikan penularan COVID-

19 khususnya di daerah Bali, dengan dibentuk Satgas Gotong Royong yang melibatkan pecalang, hansip, karang taruna, Babinsa, dan Babinkantibmas, dan sukarelawan. Kebijakan tersebut cukup efektif dalam mengendalikan penyebaran COVID-19 di Bali. Pelibatan semua komponen masyarakat akan menyebabkan perilaku pencegahan penyebaran COVID-19 yang semakin masif (Yasa, 2020).

\section{SIMPULAN}

Simpulan yang dapat ditarik pada penelitian ini adalah tindakan pencegahan COVID-19 yang dilakukan oleh mahasiswa Universitas Udayana dalam kategori cukup baik yaitu 61,25\%. Adapun aspek tindakan pencegahan COVID-19 oleh mahasiswa Universitas Udayana diantaranya selalu pakai masker ketika di luar rumah 96,25\%, memakai masker dengan menutupi mulut, hidung dan dagu 95\%, cuci tangan pakai sabun/pakai handsanitizer 98,75\%, selalu jaga jarak minimal satu meter saat bertemu orang lain $71,25 \%$, tidak sering mengunjungi tempat keramaian 52,50\%, menerapkan etika batuk dan bersin 96,25\%, tidak sentuh mulut, hidung, dan mata sebelum cuci tangan $70 \%$, dan langsung berganti pakaian saat tiba di rumah $78,75 \%$. Berdasarkan hasil uji regresi logistik sederhana menunjukkan karakteristik sosiodemografi seperti jenis kelamin, status pekerjaan, dan riwayat penyakit komorbid pada orang tua sebagai faktor risiko terhadap tindakan pencegahan COVID-19. Sedangkan usia, fakultas, dan pengetahuan bukan sebagai faktor risiko pada tindakan pencegahan COVID-19.

\section{SARAN}

Saran dalam penelitian ini adalah hasil penelitian menemukan tindakan pencegahan COVID-19 pada mahasiswa Universitas Udayana tergolong cukup baik. Mahasiswa sering mengunjungi tempat keramaian seperti mall, tempat wisata, dan pantai dan sering sentuh mulut, hidung, dan mata sebelum cuci. Oleh karena itu, perlu dilakukan pengoptimalan perilaku pencegahan COVID-19 pada mahasiswa Universitas Udayana. Organisasi kemahasiswaan turut berperan aktif mengkampanyekan gerakan pencegahan COVID-19 secara masif baik berupa poster atau video edukasi melalui media sosial untuk mengoptimalkan tindakan pencegahan COVID-19 yang lebih baik oleh mahasiswa Universitas Udayana. Bagi peneliti yang tertarik dengan topik ini bisa meneliti faktor determinan memengaruhi tindakan pencegahan COVID-19 yang buruk seperti mengunjungi tempat keramaian, dan sentuh mulut, hidung, dan mata sebelum cuci tangan.

\section{UCAPAN TERIMA KASIH}

Terimakasih kepada seluruh mahasiswa Universitas Udayana yang telah berkenan menjadi responden penelitian. Pimpinan Universitas Udayana yang telah memberikan alternatif ujian skripsi berupa ujian secara daring.

\section{DAFTAR PUSTAKA}

Alzoubi, H., Alnawaiseh, N., Al-Mnayyis, A., Lubad, M. A., Aqel, A., \& Al- 
Shagahin, H. (2020). COVID-19Knowledge, Attitude and Practice Among Medical and Non-Medical University Students in Jordan. J Pure Appl Microbiol, 14(1), 17-24.

Andrews, J. L., Foulkes, L., \& Blakemore, S.-J. (2020). Peer Influence in Adolescence: Public-Health Implications for COVID-19. Trends in Cognitive Sciences, 24(8), 585-587.

BPS RI. (2020). Hasil Survei Perilaku Masyarakat Di Masa Pandemi Covid-19 (7-14 September 2020) (Vol. 19).

CDC. (2020). People with Certain Medical Conditions. Available: https://www.cdc.gov/coronavirus/201 9-ncov/need-extraprecautions/people-with-medicalconditions.html\#diabetes (Accessed: 2021, January 19).

Cohen, A. K., Hoyt, L. T., \& Dull, B. (2020). A Descriptive Study of COVID-19Related Experiences and Perspectives of a National Sample of College Students in Spring 2020. Journal of Adolescent Health, 67(3), 369-375.

Ferdous, M. Z., Islam, M. S., Sikder, M. T., Mosaddek, A. S. M., ZegarraValdivia, J. A., \& Gozal, D. (2020). Knowledge, Attitude, and Practice regarding COVID-19 Outbreak in Bangladesh: An Online-based CrossSectional Study. PloS One, 15(10), e0239254.

Gao, H., Hu, R., Yin, L., Yuan, X., Tang, H., Luo, L., ... Yu, A. (2020). Knowledge, Attitudes and Practices of the Chinese Public with Respect to Coronavirus Disease (COVID-19): An Online Cross-Sectional Survey. BMC Public Health, 20(1), 1-8.

Hatabu, A., Mao, X., Zhou, Y., Kawashita, N., Wen, Z., Ueda, M., ... Tian, Y.-S.
(2020). Knowledge, Attitudes, and Practices Toward COVID-19 Among University Students in Japan and Associated Factors: An Online CrossSectional Survey. PloS One, 15(12), e0244350.

Huang, C., Wang, Y., Li, X., Ren, L., Zhao, J., Hu, Y., .. Gu, X. (2020). Clinical Features of Patients Infected with 2019 Novel Coronavirus in Wuhan, China. The Lancet.

Kemenkes RI. (2020). Buku Panduan Kampus Siaga COVID-19.

Nursalam. (2014). Metodologi Penelitian Ilmu Keperawatan. Jakarta: Salemba Medika.

Olaimat, A. N., Aolymat, I., Elsahoryi, N., Shahbaz, H. M., \& Holley, R. A. (2020). Attitudes, Anxiety, and Behavioral Practices Regarding COVID-19 Among University Students in Jordan: a Cross-Sectional Study. The American Journal of Tropical Medicine and Hygiene, 103(3), 11771183.

Peng, Y., Pei, C., Zheng, Y., Wang, J., Zhang, K., Zheng, Z., \& Zhu, P. (2020). Knowledge, Attitude and Practice Associated with COVID-19 Among University Students: a CrossSectional Survey in China. BMC Public Health, 20, 1292.

Saefi, M., Fauzi, A., Kristiana, E., Adi, W. C., Muchson, M., Setiawan, M. E., ... Ramadhani, M. (2020). Survey Data of COVID-19-Related Knowledge, Attitude, and Practices Among Indonesian Undergraduate Students. Data in Brief, 31, 105855.

Sari, A. R., Rahman, F., Wulandari, A., Pujianti, N., Laily, N., Anhar, V. Y., ... Muddin, F. I. (2020). Perilaku Pencegahan Covid-19 Ditinjau dari 
Karakteristik Individu dan Sikap Masyarakat. JPPKMI, 1(1).

Satgas COVID-19. (2021). Peta Sebaran. Available: https://covid19.go.id/ (Accessed: 2021, February 8).

Syadidurrahmah, F., Muntahaya, F., Islamiyah, S. Z., Fitriani, T. A., \& Nisa, H. (2020). Perilaku physical distancing mahasiswa UIN Syarif Hidayatullah Jakarta pada masa pandemi covid-19. Perilaku Dan Promosi Kesehatan: Indonesian Journal of Health Promotion and Behavior, 2(1), 29-37.

Syakurah, R. A., \& Moudy, J. (2020). Pengetahuan terkait Usaha Pencegahan Coronavirus Disease (COVID-19) di Indonesia. HIGEIA (Journal of Public Health Research and Development), 4(3), 333-346.

Tuwu, D. (2020). Kebijakan Pemerintah dalam Penanganan Pandemi COVID19. Journal Publicuho, 3(2), 267-278.

WHO. (2020a). Coronavirus. Available: https://www.who.int/healthtopics/coronavirus\#tab=tab 1 (Accessed: 2020, December 24).
WHO. (2020b). COVID-19 Public Health Emergency of International Concern (PHEIC) Global Research and Innovation Forum. Available: https://www.who.int/publications/m/ item/covid-19-public-healthemergency-of-international-concern(pheic)-global-research-andinnovation-forum (Accessed: 2020, December 30).

Wrzus, C., Hänel, M., Wagner, J., \& Neyer, F. J. (2013). Social Network Changes and Life Events Across the Life Span: A Meta-Analysis. Psychological Bulletin, 139(1), 53.

Wu, Z., \& McGoogan, J. M. (2020). Characteristics of and Important Lessons From the Coronavirus Disease 2019 (COVID-19) Outbreak in China: Summary of a Report of 72314 Cases From the Chinese Center for Disease Control and Prevention. JAMA. https://doi.org/10.1001/jama.2020.264 8

Yasa, I. W. P. (2020). Tri Hita Karana untuk Pencegahan COVID-19 di Bali. Jurnal Socius: Journal of Sociology Research and Education, 7(1), 54-66. 